Article

\title{
Integrated Healthcare and the Dilemma of Public Health Emergencies
}

\author{
Krzysztof Goniewicz ${ }^{1, *}\left(\mathbb{D}\right.$, Eric Carlström ${ }^{2,3}{ }^{\oplus}$, Attila J. Hertelendy ${ }^{4,5}$, Frederick M. Burkle ${ }^{6}$, \\ Mariusz Goniewicz ${ }^{7}$ (D), Dorota Lasota ${ }^{8}(\mathbb{D})$, John G. Richmond ${ }^{9}$ (D) and Amir Khorram-Manesh ${ }^{3,10,11, *(D)}$
}

check for updates

Citation: Goniewicz, K.; Carlström, E.; Hertelendy, A.J.; Burkle, F.M.; Goniewicz, M.; Lasota, D.; Richmond, J.G.; Khorram-Manesh, A. Integrated Healthcare and the Dilemma of Public Health Emergencies. Sustainability 2021, 13, 4517 . https://doi.org/10.3390/su13084517

Academic Editor: Maxim A. Dulebenets

Received: 31 March 2021 Accepted: 16 April 2021 Published: 19 April 2021

Publisher's Note: MDPI stays neutral with regard to jurisdictional claims in published maps and institutional affiliations.

Copyright: (c) 2021 by the authors. Licensee MDPI, Basel, Switzerland. This article is an open access article distributed under the terms and conditions of the Creative Commons Attribution (CC BY) license (https:// creativecommons.org/licenses/by/ $4.0 /)$.
1 Department of Aviation Security, Military University of Aviation, 08-521 Dęblin, Poland

2 Institute of Health and Care Sciences, Sahlgrenska Academy, University of Gothenburg, 40530 Gothenburg, Sweden; eric.carlstrom@gu.se

3 Gothenburg Emergency Medicine Research Group (GEMREG), Sahlgrenska Academy, 40530 Gothenburg, Sweden

4 Department of Information Systems and Business Analytics, College of Business, Florida International University, Miami, FL 33199, USA; attila.hertelendy@georgetown.edu

5 Fellowship in Disaster Medicine, Department of Emergency Medicine, Beth Israel Deaconess Medical Centre, Boston, MA 02215, USA

6 Harvard Humanitarian Initiative, T.H. Chan School of Public Health, Harvard University, Boston, MA 02115, USA; skipmd77@aol.com

7 Department of Emergency Medicine, Medical University of Lublin, 20-059 Lublin, Poland; mariusz.goniewicz@umlub.pl

8 Department of Experimental and Clinical Pharmacology, Medical University of Warsaw, Banacha 1b Street, 02097 Warsaw, Poland; dorota.lasota@wum.edu.pl

9 School of Health and Related Research, The University of Sheffield, Sheffield S10 2TN, UK; j.g.richmond@sheffield.ac.uk

10 Institute of Clinical Sciences, Department of Surgery, Sahlgrenska Academy, Gothenburg University, 41345 Gothenburg, Sweden

11 Department of Development and Research, Armed Forces Center for Defense Medicine, Gothenburg, 42676 Västra Frölunda, Sweden

* Correspondence: k.goniewicz@law.mil.pl (K.G.); amir.khorram-manesh@surgery.gu.se (A.K.-M.)

Abstract: Traditional healthcare services have demonstrated structural shortcomings in the delivery of patient care and enforced numerous elements of integration in the delivery of healthcare services. Integrated healthcare aims at providing all healthcare that makes humans healthy. However, with mainly chronically ill people and seniors, typically suffering from numerous comorbidities and diseases, being recruited for care, there is a need for a change in the healthcare service structure beyond direct-patient care to be compatible in peacetime and during public health emergencies. This article's objective is to discuss the opportunities and obstacles for increasing the effectiveness of healthcare through improved integration. A rapid evidence review approach was used by performing a systematic followed by a non-systematic literature review and content analysis. The results confirmed that integrated healthcare systems play an increasingly important role in healthcare system reforms undertaken in European Union countries. The essence of these changes is the transition from the episodic treatment of acute diseases to the provision of coordinated medical services, focused on chronic cases, prevention, and ensuring patient continuity. However, integrated healthcare, at a level not yet fully defined, will be necessary if we are to both define and attain the integrated practice of both global health and global public health emergencies. This paper attains the necessary global challenges to integrate healthcare effectively at every level of society. There is a need for more knowledge to effectively develop, support, and disseminate initiatives related to coordinated healthcare in the individual healthcare systems.

Keywords: healthcare; integrated care; integrated healthcare delivery; quality of healthcare; hospital management 


\section{Introduction}

Although there might be national differences in defining Integrated Healthcare (IHC), one can simply describe it as efforts needed to provide all healthcare services that make humans healthy [1]. Consequently, such provision necessitates valid and functional delivery systems at all times. The World Health Organization (WHO) defines an integrated delivery system as, "the organization and management of health services so that people get the care they need, when they need it, in ways that are user-friendly, achieve the desired results, and provide value for money" [2]. These definitions work well in peacetime and with intact resources and capabilities. However, the last decades' economic strain on healthcare systems and an increasing number of public health emergencies highlight the insufficiency of delivering integrated healthcare, particularly to vulnerable groups of a society [3]. IHC is one of the important concepts related to the management and organization of healthcare systems. At present, efforts to integrate the process of providing healthcare, in addition to the integration of other areas of socio-economic life with the healthcare system, are a major concern for many international entities like WHO [2]. Attention to this concern is seen through a variety of projects that either directly or indirectly orient towards coordinating the provision of healthcare. By implementing these projects, healthcare systems aim to obtain the interrelated goals of improving the effectiveness of treatment, attribution of costs, and leveling inequalities in the access to and utilization of medical care [2].

In consideration of the concept of efficiency with these goals, there are three dimensions: market efficiency, cost-effectiveness, and social efficiency [4]. Market efficiency describes the maximization of health benefits to a population through the allocation of healthcare services that consider the cost incurred per activity. Cost-effectiveness describes the construction of a particular number of services at a minimum of cost. As such, costeffectiveness allows a more accurate assessment of the costs of a particular service [5] through an outcome analysis of a particular healthcare entity's service activities concerning the amount of cost incurred. In practice, efforts to improve efficiency aim to maximize the outcomes of service activities at specific input levels or by obtaining desired outcomes with minimal expenditure [6]. Social efficiency is associated with progress towards the implementation of social tasks, which benefit the healthcare system as seen in improving the combined health of societal groups or improving the quality and availability of healthcare at differing levels for a certain population.

Market and social efficiency are macro-level constructs, which consider the ratio of costs to benefits in the healthcare sector with the broader national economy and population equity [7]. Efficiencies derived at the micro-level do not equate with efficiency at the macrolevel, particularly where a fragmented and non-equal healthcare industry is present. As such, healthcare expenditure is viewed in light of, and competing with, other expenditures at a national scale. This raises legitimate economic and social concerns on healthcare influences upon human health. This results in a problem of weighing the opportunity cost of various wants and needs, which can contribute to a fragmented healthcare system leading to the abandonment of frail patients. These are the same vulnerable victims of public health emergencies.

Stakeholders and politicians [8-10] have long praised integration. It is supported by mutual respect and prospects and is facilitated by endurance $[10,11]$. However, any integration, especially among independent parties, may create conflicts [8-14], resulting in failing to deliver or delivering insufficiently, if pushed too far $[10,12]$. Within healthcare, integration is "an approach to strengthening patient-centered health systems through the promotion of the comprehensive delivery of quality services across the life-course designed according to the multidimensional needs of the population and the individual and delivered by a coordination of health-care providers working across settings and levels of care". Although this model ensures optimal outcomes and the appropriate use of resources based on the best available evidence, utilizes feedback loops to continually improve performance, tackles upstream causes of ill health, and promotes well-being through inter-sectoral and multi-sectoral actions, it may also create some difficulties, particularly times of crisis 
and public health emergencies and among underserved communities and vulnerable groups of a society [3,15]. The purpose of this study is to review the current concerns and shortcomings of IHC systems and to analyze the available opportunities and existing obstacles to improve their efficiency in delivery.

\section{Materials and Methods}

A Rapid Evidence Review approach was used by performing a systematic literature search, followed by a non-systematic literature review during January-March 2021. This approach summarizes the available state-of-the-art even if quantitative outcome data is unavailable in the literature [14].

The following search engines were used: Google Scholar, PubMed, Scopus, Science Direct, and University Library search engines in Poland and Sweden.

Using the following keywords: "Integrated Healthcare" AND “Delivery" AND “Utilization" AND "Pros" AND "Improvement", a high number of hits was obtained. The search was then limited to the years 2010-2021 and for the publications in English. Two researchers (KG, and A K-M) conducted the search independently, and the outcomes were then matched. The included articles were chosen based on consensus between KG and A $\mathrm{K}-\mathrm{M}$, and if needed a third author was contacted.

Included studies: Original publications and reviews from January 2010 to March 2021.

Excluded studies: Proceedings, editorials, meeting notes, news, abstracts, and nonrelevant papers.

Finally, a qualitative thematic analysis of the included literature based on an inductive approach was applied. This content analysis aimed to study all included articles, focusing on similarities and differences in the findings to present the tentative results [16].

\section{Results}

The search started by using each keyword alone or in combination. The initial keyword, such as Integrated Healthcare or Integrated Health Systems, returned too many hits, which gradually were filtered by adding new keywords and limiting the search period. Table 1 shows the reduction of hits after adding new keywords (Table 1). The obtained hits from all search engines were selected according to the study's inclusion and exclusion criteria to achieve a feasible number of articles for this review (Figure 1). The thematic results were then presented in sections and topics (Section 3.1, Section 3.2).

Table 1. The results of initial filtering of the hits in each search engines.

\begin{tabular}{|c|c|c|c|c|c|}
\hline Engine & "Integrated Healthcare" & "Delivery" & "Utilization" & "Pros" & "Improvement" \\
\hline Google Scholar & 17,700 & 16,000 & 7320 & 369 & 287 \\
\hline Pub Med & 1380 & 1090 & 96 & 96 & 9 \\
\hline Scopus & 19,440 & 11,518 & 4586 & 271 & 220 \\
\hline Science Direct & 3560 & 1960 & 840 & 165 & 117 \\
\hline Total & 42,080 & 30,568 & 12,842 & 901 & 633 \\
\hline
\end{tabular}

\subsection{Healthcare Integration between Different Levels}

According to the World Health Organization, IHC is a combination of inputs, delivery, management, and the organization of services associated with diagnosis, treatment, care, rehabilitation, and health promotion. Integrated care aims to improve the access, quality, user satisfaction, and efficiency of healthcare services [17]. Others define integrated care as a worldwide trend in healthcare reforms and new organizational arrangements focusing on more coordinated and integrated forms of care provision [18]. The system of integrated provision of health services requires integration at three levels: organizational, clinical, and individual [19]. However, these levels, divided into subgroups, are interrelated and have mutual factors, which may affect the outcomes of IHC. 


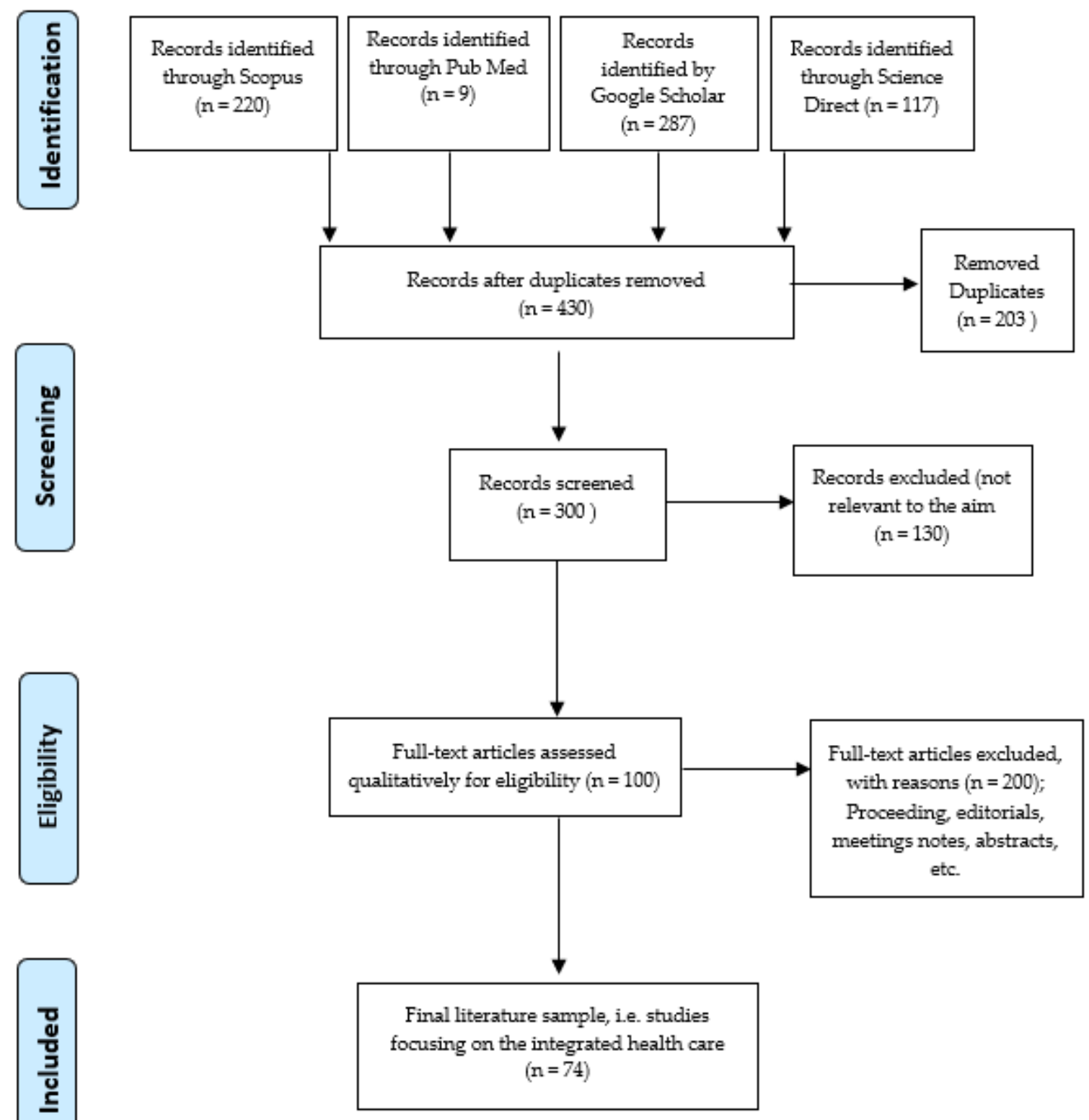

Figure 1. Flow diagram of included records for this study.

\subsubsection{Organizational Integration}

Integration can occur vertically or horizontally. By using both vertical and horizontal directions of integration, an integrated service delivery network can create a system of cooperating programs, entities, or health plans at the equivalent level of care and between its various levels [20]. While the influence of tasks enacted by this type of system mainly affects the economic and clinical levels, integration might also benefit patient satisfaction by improving relationships with patients through better continuity of treatment and safeguarding a sense of health security [21]. This multi-level system offers opportunities to deliver high-quality care to patients if working appropriately at all levels, otherwise, may generate more suffering.

While the approach to healthcare integration and coordination strategies might vary by country, the process of transformation is similar. Key factors on the supply side include potential economic pressure on the cost management of healthcare systems and the development of medical technologies and IT systems [22]. Considerations on the demand side include 
demographic and epidemiological changes in society, patient empowerment in the form of stronger voices for their needs and preferences, and organized consumer movements.

\subsubsection{The Aging Patient}

The growing life expectancy rate and the growth of the segment of people in the 65+ group undoubtedly affect the volume and structure of the demand for healthcare. Over the past 30 years alone, the percentage of the population aged 65+, calculated as the European Union (EU) average, increased from 13\% in 1980 to around 20\% in 2019 [23,24]. The trend toward higher life expectancy alone does not allow for accurately estimating the demand for health services. Elements, such as individual lifestyle, environment, and genetic risk factors must also be considered in calculations and weighed alongside the emergence of health problems that are known to arise with old age and new diseases [25-27]. This explains why the demand for health services in an aging society, especially in Europe, is described by functional, psychological, and social consequences of chronic and multi-organ diseases. The most appropriate answer to dealing with these problems synchronously is IHC, which primarily refers to the holistic approach to human health [28].

\subsubsection{Disease Panorama}

Treatment of increasingly common ascending chronic diseases will require moving away from the fragmentation of healthcare and focusing on so-called acute diseases, and short-term hospitals adapted to combat the management of the patient's disease unit together with a social and environmental support system. A transition to a patient-centered healthcare model from existing disease-, technology-, physician-, and hospital-centric models is essential $[29,30]$. A consequence of patient-centered healthcare is that changes occur to both the supply and demand side of the health system. On the supply side, the distribution of financing health services is based on need and solidarity and on the demand side, patients take increased responsibility for their health, in addition to the financial implications. A fundamental issue that will need to be resolved is the sharing of risk between all parties involved in the provider-payer-patient relationship [31].

Another opportunity results from patients having greater access to medical information and globalization, which results in higher expectations from patients than what the current healthcare delivery system in most countries can support [32]. The increasing demand from patients for the availability of healthcare, continuity of care, and comprehensiveness translates to the increased responsibility of the healthcare institutions to provide greater management, health promotion, and extensive rehabilitation. Meanwhile, the rise of patient empowerment is linked to improved disease self-management [32-35] and a desire to take control of one's health through lifestyle change and establishing a healthy environment [36].

\subsubsection{The Advancing Technology}

Ongoing advances in information and communication technologies (ICT) are a factor on the supply side of healthcare that is thought to have the most significant impact on progress towards integration [37]. ICT, by facilitating information flows between treatment participants at differing levels, improves the quality of care. These technologies also enable the interested system stakeholders to monitor the effectiveness of the care process through feeding back relevant metrics and data. This feedback enables vertical integration of organization and information to support the processes involved in providing medical services [38].

At the meso level, the integration of professionals and institutions into interdisciplinary teams enables sharing of experience and knowledge and is facilitated by ICT [39]. This represents a form of horizontal integration in terms of sharing know-how. For the patient, the advantages of ICT are an increase in the speed of diagnosis and that treatment can be started remotely without in-person attendance [40]. Telemedicine, a popular form of 
ICT, increases the availability of services for patients living outside large specialist centers, enhancing support for social efficiency.

When considering the macro level, the influx of epidemiological data and results provided by ICT enables more effective planning for the allocation of healthcare services. Furthermore, the costs of obtaining medical research data and evidence are reduced, hence increasing the evidence base for the provision of care based upon scientific research [41,42]. Over time, the adoption of new medical technology will force an adjustment in the existing structures and forms of healthcare service delivery. Additional opportunities for integration are supported where ICT can, for example, cut down queues in busy walk-in centers in populated areas or prehospital triage, and provide decision support tools for advisory call centers.

\subsubsection{Community Commitments: Supply and Services}

Increasing outpatient and community level care service provision, including home care, can reduce patients' length of stay (LOS) and lower admissions in hospitals [43]. More innovative approaches such as gene therapy will necessitate completely new forms of healthcare delivery and considerations for novel organizational and logistical solutions. However, new technologies like gene therapy may prove more cost-effective than current ones as coordination between existing outpatient and specialized healthcare levels is a challenge [44].

On the supply side, one must consider the phenomenon of demand induced by supply, a well-known macroeconomic problem [45]. This leads to an increase in expenditure. For example, if we were able to shorten the LOS for a hospital in-patient through new technology, we may indirectly induce an increase in the demand for beds. This would in turn lead to new hospital admissions and potential misuse of resources where patient admissions are shifted to other parts of the hospital leading to worsening patient safety and increased risk for spreading infectious disease.

However, social efficiency is increasing due to the increased service capacity at various levels of healthcare, improving the access to services [46]. Improving efficiency at the macro scale is possible through system harmonization and consolidation of links between individual levels of care. In light of the progressing specialization and fragmentation of medicine, this goal may be difficult to achieve [47].

\subsection{IHC Model Across International Healthcare Systems}

The scope of competence and tasks of a general physician (GP) and the care carried out is characterized by certain features, which are different from the specifics of the work of specialists in narrow fields of medicine [48,49]. Specialists focus more on a targeted organ such as the heart or kidney. The family doctor provides comprehensive care for the patient, family, and the local community. Characteristic features of GP activity include, among others: comprehensiveness, continuity, patient orientation, and coordination [50]. GPs may play a significant role in the execution of IHC, however, overcrowded Emergency Departments in most western countries indicate that the GP's position as an integrating actor is still undeveloped.

In Europe, Scandinavian countries have been successful in advancing IHC delivery throughout the national health system [51,52]. In other countries, such as Poland, healthcare providers have also succeeded in introducing integrated care solutions [53-55]. However, the introduction of integrated care differs between countries in terms of the scope and type of solutions used, which may be systemic, aimed at reducing barriers between sectors of the healthcare system or improving cooperation between medical professionals. This can be seen in Scandinavian countries, with almost similar cultural and behavioral backgrounds. While Norway approaches IHC by individual plans and legislation, with a strong local character, the Danish approach is conducted in a top-down manner and a traditional bureaucratic culture. Sweden, on the other hand, practices IHC as a voluntary collaborative 
task in a locally initiated and conducted development work to deliver an improved health service to the patients [56].

In other EU countries, initiatives integrating health and social care have been implemented by creating housing estates adapted to the lives of the chronically ill [57-64]. A review by Nolte and Knai indicated the existence of numerous chronic disease management initiatives across 12 European countries [65]. Although the majority of approaches focused on populations with defined conditions (e.g., diabetes, asthma, cardiovascular disease, cancer), they often involve elements of integration between providers and sectors. It could involve the implementation of multidisciplinary teams and care coordination among different professions as well as building providers' networks.

In a recent study, integrated care models were systematically reviewed and compared between the UK and several other countries. The result indicated that higher patient satisfaction, increased perceived quality of care, and increased patient access to services are the three most frequent indicators of care integration [66]. The same results were also found in another review, comparing six Asian countries, including Singapore, China, India, Vietnam, etc. [67].

In developed countries, coordination of healthcare reflects the cooperation between primary healthcare and other healthcare systems $[65,68]$. It assures the optimization of medical decisions from a financial perspective. From the patient's point of view, a physician's action consists of medical counselling and acting as a guide to a complex healthcare system [69]. From the system administrator's point of view, it is perceived as an element of access control to cost-intensive specialists and hospital services [70]. The concept of coordination is also extended to activities that go beyond healthcare, perceived as cross-sectoral cooperation, which includes the system of social care, education, environmental protection, and the workplace [71].

\subsection{Nearness to Death (NTD)}

Studies show that some 55\% of a person's entire lifetime hospital bed use occurs in the last year of life, and thus disproves the claim that population growth and ageing are the causes of steady healthcare demands [72]. Considering that this period of life is associated with higher costs, in terms of investigations and bed occupancy, it is logical to believe that major changes need to occur in terms of end-of-life costs. NTD should thus be considered in capacity planning models to provide realistic estimates of future bed demands [73]. New studies in the UK show that the demand for medical beds is likely to increase by 39\% until 2060 [74]. Planning is needed for both adults and pediatric patients [75]. Supporting legislation is an absolute necessity for successful integrated healthcare to not only guide the care of patients in peacetime and emergencies but also for the implication of nearness to death as the patients must at some point be diverted from further aggressive care into more palliative alternatives [76-78].

\section{Discussion, Challenges, and Recommendations}

Although IHC provides high quality of care from national and global perspectives and is both praised and supported by stakeholders and politicians, it must function in harmony and mutual respect and prospects for all involved parties. The imbalance between needs and demand in underserved communities and during national and international emergencies may influence its efficiency and create some difficulties, resulting in insufficient or failed delivery [8-15]. Within healthcare, a chief concern is the fragmentation between public and private healthcare models within a common context. In some countries, a mix of Beveridge, Bismarck, and out-of-pocket healthcare systems is practiced side by side. Such a mix may provide freedom of choice but may also hinder equity because of difficulties to transfer patients between systems [54,58-64]. Such an imbalance and health inequity would be more during crises.

Digitalization may be a tool to improve transferability, but an optimized flexible system of resource allocation is a necessary remedy to limit fragmentation. To prevent frag- 
mentation, all steps in the digitalization process of health services have to place the patients first and the process itself has to help the patients through the procedures and services available at their disposal. However, a major challenge for modern medicine is an ageing society, which generates increasing medical costs. According to a United Nations (UN) report, the ageing of society is an unprecedented demographic trend determining significant changes in all areas of life by at least 2050 [79], emphasizing why the social support system for the elderly as part of policymaking for seniors is becoming an enormous challenge.

There is a need to develop a long-term healthcare strategy. This requires systematic measurement, and comparison of health outcomes, nationally and globally, to improve the outcomes. Maps of health needs are undoubtedly a tool enabling such measurements and analysis of health data, whereas, according to many authors, the essential tool supporting the planning and coordination of healthcare, used for communication with the patient, is electronic medical documentation [42-46]. This documentation is also necessary for the effective use of telemedicine and e-health mobile solutions in health service delivery [80-83]. However, digitalization may create some difficulties in extreme situations and during disasters in obtaining the necessary authorization to access patients' data and should be considered in the early planning phases.

Applying the Pareto principle, modern healthcare systems typically see $80 \%$ of their expenditures consumed by $20 \%$ of patients $[83,84]$. Driving this trend is the recruitment of mainly seniors and chronically ill people who suffer from numerous co-morbidities and diseases. As such, a need for change in the overlying structure of health services may emerge. A further challenge, particularly for GPs is to consider patient priorities and values including the need to involve patients in joint decision-making so that the best solutions can be planned regarding prevention, diagnosis, and therapy. Quality improvement to care for chronically ill people is also called for by numerous reports which highlight pressures to keep expenses down and to manage these patients more efficiently $[85,86]$.

Several organizational and individual factors affect the outcomes of IHC. These factors, not only play a significant role in daily healthcare delivery to underserved communities but also enhance the negative outcomes of public health emergencies. The world has been successful in globalizing communications and travel through integrated policies and practices not seen before. Whereas traditional healthcare practices can manage infectious disease outbreaks and epidemics, it has failed in the current Coronavirus Disease 2019 pandemic, which requires several elements of integration beyond current direct-patient care $[87,88]$. Worse, in many countries, especially the United States, the pandemic destroyed the one highly IHC system, that of public health, forcing it to acquiesce to economic and political demands. Integrated healthcare, at a level not yet fully defined, will be necessary if we are to attain the goal of an integrated practice of both global health and global public health [89-92]. To overcome these global challenges, we must first effectively integrate healthcare at every level of society.

\section{Limitations}

This article does not discuss all initiatives and solutions to improve the effectiveness of IHC, rather we have focused on identifying the solutions that seem to be the most beneficial due to a large number of policy proposals, especially in domestic markets. Another limitation to this study is its dependency on English literature. Other definitions or discussions about IHC in other languages were not searched for and thus some important data might be missing. Finally, although the literature selection was conducted independently by two authors, according to a defined topic and consensus, there might still be some bias and some of the excluded studies might have had an impact on the final discussion and conclusion.

\section{Conclusions}

Healthcare systems in many European countries have been experiencing severe difficulties for many years, mainly due to inadequate funding of the healthcare system [93]. 
These problems manifest themselves by demanding access to specialist care and long queues awaiting benefits, the unsatisfactory quality of health services, low wages in the healthcare sector, mass emigration of specialist medical staff to wealthier EU countries, and the indebtedness of public healthcare facilities [94]. Coordinated global healthcare is an essential and effective strategy to achieve the needed reform in health systems across Europe. It can take many different forms and can be implemented using a variety of organizational and financial models [95]. However, its implementation in individual systems requires the integration of health and social policy and cooperation between the market regulator, the payer, and medical service providers, as well as the patient's involvement [6-13].

Coordinated healthcare is necessary for the patient, the service provider, the payer himself, and the governmental institutions. These policies might also need to be compatible in both peacetimes and during public health emergencies. Such compatibility needs educational initiatives [96] in all levels of disaster management to be implemented during a period and resource scarcity. More knowledge is needed to effectively develop, support, and disseminate initiatives related to coordinated healthcare in individual healthcare systems of different countries and during different scenarios [97-102]. It is equally important to pay attention to initiatives, which will allow the creation of better and enhanced technical and organizational solutions, as well as change the behavior of patients and healthcare providers.

\section{Recommendations}

1. The most crucial element to achieving integrated healthcare for use in both peacetimes and public health emergencies is interagency or interdisciplinary collaboration.

2. Community support and resources are significant factors to unburdening emergency healthcare. Mutual planning and considerations between various healthcare branches for the care of chronically ill patients and those in terminal disease are mandatory.

3. Nearness to death should be included as one important factor in future healthcare planning and integrated healthcare.

4. Technological advances should be used based on evidence and according to the prognostic outcome of patients.

Author Contributions: K.G. provided the main framework, identified and organized primary materials, conducted the literature search and collection, and collaborated on writing the manuscript. E.C. identified appropriate references and collaborated on the writing of the manuscript. F.M.B. was involved in data analysis, interpretation, and collaborated on the writing of the manuscript. A.J.H., M.G., D.L. and J.G.R. contributed to drafting sections of the manuscript. A.K.-M. collaborated on the writing, literature search and collection, and editing of the paper. All authors have read and agreed to the published version of the manuscript.

Funding: This research received no external funding.

Institutional Review Board Statement: Not applicable.

Informed Consent Statement: Not applicable.

Data Availability Statement: Not applicable.

Acknowledgments: The authors would like to thank Katarzyna Dubas-Jakóbczyk from Jagiellonian University in Poland, whose insightful comments helped improve the paper.

Conflicts of Interest: The authors declare no conflict of interest.

\section{References}

1. Courtnage Courtnage, T.; Bates, N.E.; Armstrong, A.A.; Seitz, M.K.; Weitzman, T.S.; Fann, J.R. Enhancing integrated psychosocial oncology through leveraging the oncology social worker's role in collaborative care. Psycho-Oncology 2020, 29, $2084-2090$. [CrossRef] [PubMed]

2. World Health Organization. Transforming Integrated Health Service Delivery in the WHO European Region. Available online: http:/ / www.euro.who.int/en/health-topics/Health-systems/health-services-delivery/news/news/2016/05/transformingintegrated-health-service-delivery-in-the-who-european-region (accessed on 5 March 2021). 
3. Khorram-Manesh, A.; Yttermyr, J.; Sörensson, J.; Carlström, E. The Impact of Disasters and Major Incidents on Vulnerable Groups: Risk and Medical Assessment of Swedish Patients with Advanced Care at Home. Home Health Care Manag. Pract. 2017, 29, 183-190. [CrossRef]

4. Hetrick, S.E.; Bailey, A.P.; Smith, K.E.; Malla, A.; Mathias, S.; Singh, S.P.; O’Reilly, A.; Verma, S.K.; Benoit, L.; Fleming, T.M.; et al. Integrated (one-stop shop) youth health care: Best available evidence and future directions. Med. J. Aus. 2017, 207, S5-S18. [CrossRef] [PubMed]

5. Auschra, C. Barriers to the integration of care in inter-organisational settings: A literature review. Int. J. Integr. Care 2018, 18. [CrossRef]

6. World Health Organization Regional Office for Europe. Strengthening People-Centred Health Systems in the WHO European Region: Framework for Action on Integrated Health Services Delivery. 2016. Available online: http://www.euro.who.int/__ data/assets/pdf_file/0004/315787/66wd15e_FFA_IHSD_160535.pdf?ua=1 (accessed on 5 March 2021).

7. Rogers, L.; De Brún, A.; Mcauliffe, E. Defining and assessing context in healthcare implementation studies: A systematic review. BMC Health Serv. Res. 2020, 20, 1-24. [CrossRef]

8. Berg, I.K. Family-Based Services: A Solution-Focused Approach; WW Norton \& Co.: New York, NY, USA, 1994.

9. Boklund Palm, A. Olikheter Som Berikar: Möjligheter Och Hinder I Samarbetet Mellan Socialtjänstens äLdre- Och Handikappomsorg, Barnomsorg Samt Individ- Och Familjeomsorg = [Enriching Dissimilarities]: [Co-Operation Within the Local Social Services in Sweden]; Stockholm University: Stockholm, Sweden, 1995.

10. Danermark, B.; Kullberg, C. The Welfare States New Working Pattern; Studentlitteratur: Lund, Sweden, 1999.

11. Lind, J.I.; Hellström, C. Organisational Learning: New Perspectives on Changes in Swedish Social Services; Liber-Hermod: Uppsala, Sweden, 1996.

12. Waks, C. Organisation of Work and Professional Boundaries: The Co-operation of Physiotherapists and the Diversity of Work (English). Ph.D. Thesis, Uppsala University, Uppsala, Sweden, 2003.

13. Gynnerstedt, K. Ethic in Home Care; En studie av förvaltnings- och professionsetik; Studentlitteratur: Lund, Sweden, 1993.

14. Sjöstedt, E.; Nordström, L.; Singh, D.J. An alternative way of linearizing the augmented plane-wave method. Solid State Commun. 2000, 114, 15-20. [CrossRef]

15. Shaw, S.; Rosen, R.; Rumbold, B. What is Integrated Care; Nuffield Trust: London, UK, 2011.

16. Haby, M.M.; Chapman, E.; Clark, R.; Barreto, J.; Reveiz, L.; Lavis, J.N. What are the best methodologies for rapid reviews of the research evidence for evidence-informed decision making in health policy and practice: A rapid review. Health Res. Policy Syst. 2016, 14, 83. [CrossRef]

17. World Health Organization. European Health for All Database. Available online: https://gateway.euro.who.int/en/datasets/ european-health-for-all-database/ (accessed on 5 March 2021).

18. Zerbo, O.; Massolo, M.L.; Qian, Y.; Croen, L.A. A study of physician knowledge and experience with autism in adults in a large integrated healthcare system. J. Autism Devel. Dis. 2015, 45, 4002-4014. [CrossRef]

19. Baillie, L.; Gallini, A.; Corser, R.; Elworthy, G.; Scotcher, A.; Barrand, A. Care transitions for frail, older people from acute hospital wards within an integrated healthcare system in England: A qualitative case study. Int. J. Integr. Care 2014, 14, e009. [CrossRef]

20. Martínez-González, N.A.; Berchtold, P.; Ullman, K.; Busato, A.; Egger, M. Integrated care programmes for adults with chronic conditions: A meta-review. Int. J. Qual. Health Care 2014, 26, 561-570. [CrossRef] [PubMed]

21. Rudawska, I. Concept Mapping in developing an indicator framework for coordinated health care. Procedia Comput. Sci. 2020, 176, 1669-1676. [CrossRef]

22. Pirbhulal, S.; Samuel, O.W.; Wu, W.; Sangaiah, A.K.; Li, G. A joint resource-aware and medical data security framework for wearable healthcare systems. Futur. Gener. Comput. Syst. 2019, 95, 382-391. [CrossRef]

23. Sarkodie, S.A.; Strezov, V.; Jiang, Y.; Evans, T. Proximate determinants of particulate matter (PM2. 5) emission, mortality and life expectancy in Europe, Central Asia, Australia, Canada and the US. Sci. Total Environ. 2019, 683, 489-497. [CrossRef] [PubMed]

24. Van Den, H.; Wim, J.; Olaroiu, M. How important are health care expenditures for life expectancy? A comparative, European analysis. J. Am. Med. Dir. Assoc. 2017, 18, 276.e9-276.e12. [CrossRef]

25. Li, R.A.; Fisher, D.P.; Dutta, S.; O’Brien, R.M.; Ackerson, L.M.; Sorel, M.E. Sidney surgery results: Reporting clinical characteristics and adverse outcomes from an integrated healthcare delivery system. Surg. Obes. Relat. Dis. 2015, 11, 1119-1125. [CrossRef] [PubMed]

26. Rudawska, I. Towards More Integrated Health Care-The Review of the International Experience. Probl. Zarzadzania 2017, 15, 130-145. [CrossRef]

27. Tomljenović, A. Holistic approach to human health and disease: Life circumstances and inner processing. Coll. Antropol. 2014, 38, 787-792.

28. Epstein, R.M.; Fiscella, K.; Lesser, C.S.; Stange, K.C. Why the nation needs a policy push on patient-centered health care. Health Aff. 2010, 29, 1489-1495. [CrossRef] [PubMed]

29. Bechtel, C.; Ness, D.L. If you build it, will they come? Designing truly patient-centered health care. Health Aff. 2010, 29, 914-920. [CrossRef]

30. Stellefson, M.; Chaney, B.; Barry, A.E.; Chavarria, E.; Tennant, B.; Walsh-Childers, K.; Sriram, P.S.; Zagora, J. Web 2.0 chronic disease self-management for older adults: A systematic review. J. Med. Internet Res. 2013, 15, e35. [CrossRef]

31. Brady, T.J.; Murphy, L.; O'Colmain, B.J.; Beauchesne, D.; Daniels, B.; Greenberg, M.; House, M.; Chervin, D. Peer reviewed: A meta-analysis of health status, health behaviors, and health care utilization outcomes of the chronic disease self-management program. Prev. Chronic Dis. 2013, 10, 120112. [CrossRef] 
32. Ahn, S.; Basu, R.; Smith, M.L.; Jiang, L.; Lorig, K.; Whitelaw, N.; Ory, M.G. The impact of chronic disease self-management programs: Healthcare savings through a community-based intervention. BMC Public Health 2013, 13, 1141. [CrossRef] [PubMed]

33. Edelman, C.L.; Mandle, C.L.; Kudzma, E.C. Health Promotion Throughout the Life Span-e-Book; Elsevier Health Sciences: Amsterda, The Netherlands, 2017.

34. Cresswell, K.; Sheikh, A. Organizational issues in the implementation and adoption of health information technology innovations: An interpretative review. Int. J. Med. Inform. 2013, 82, e73-e86. [CrossRef]

35. Vogel, M.; Malcore, S.; Illes, R.; Kirkpatrick, H. Integrated primary care: Why you should care and how to get started. J. Ment. Health Couns. 2014, 36, 130-144. [CrossRef]

36. Evans, J.M.; Baker, R.G.; Berta, W.; Jan, B. The evolution of integrated healthcare strategies. In Academy of Management Proceedings; Academy of Management: Briarcliff Manor, NY, USA, 2013; p. 13931.

37. Melek, S.P.; Norris, D.T.; Paulus, J. Economic impact of integrated medical-behavioral healthcare. Milliman Am. Psychiatr. Assoc. Rep. 2014, 7. Available online: https://thcd.hbs.org/wp-content/uploads/sites/8/2016/09/Milliman-Report-Economic-ImpactIntegrated-Implications-Psychiatry-1.pdf (accessed on 5 March 2021).

38. D'Onofrio, G.; Sancarlo, D.; Ricciardi, F.; Panza, F.; Seripa, D.; Cavallo, F.; Giuliani, F.; Greco, A. Information and communication technologies for the activities of daily living in older patients with dementia: A systematic review. J. Alzheimer's Dis. 2017, 57, 927-935. [CrossRef] [PubMed]

39. Rudawska, I. Approaches to evaluating efficiency and quality of integrated health care: State of the evidence. Eng. Manag. Produc. Serv. 2016, 8, 7-14. [CrossRef]

40. Ajeed, M.T.; Khan, F.N. Do information and communication technologies (ICTs) contribute to health outcomes? An empirical analysis. Qual. Quant. 2019, 53, 183-206.

41. Cebul, R.D.; Rebitzer, J.B.; Taylor, L.J.; Votruba, M.E. Organizational fragmentation and care quality in the US healthcare system. J. Econ. Perspect. 2008, 22, 93-113. [CrossRef] [PubMed]

42. Setiawan, A.; Fajarini, M.; Rahayu, S. The Implementation of Evidence-Based Practice (EBP) and Information and Communication Technology (ICT)-Based Health Care Information in Depok City: Stakeholders' Perspectives; Depok City Health Office: West Java, Indonesia, 2018.

43. Attrill, S.; White, S.; Murray, J.; Hammond, S.; Doeltgen, S. Impact of oropharyngeal dysphagia on healthcare cost and length of stay in hospital: A systematic review. BMC Health Serv. Res. 2018, 18, 594. [CrossRef]

44. Schultz, K.; Griffiths, J.; Lacasse, M. The application of entrustable professional activities to inform competency decisions in a family medicine residency program. Acad. Med. 2015, 90, 888-897. [CrossRef] [PubMed]

45. Barker, L.A.; Gout, B.S.; Crowe, T.C. Hospital malnutrition: Prevalence, identification and impact on patients and the healthcare system. Int. J. Environ. Res. Public Health 2011, 8, 514-527. [CrossRef] [PubMed]

46. Karanikolos, M.; Mladovsky, P.; Cylus, J.; Thomson, S.; Basu, S.; Stuckler, D.; Mackenbach, J.P.; McKee, M. Financial Crisis, Austerity, And Health in Europe. Lancet 2013, 381, 1323-1331. [CrossRef]

47. Kern, L.M.; Seirup, J.K.; Casalino, L.P.; Safford, M.M. Healthcare fragmentation and the frequency of radiology and other diagnostic tests: A cross-sectional study. J. Gen. Intern. Med. 2017, 32, 175-181. [CrossRef] [PubMed]

48. Davoudi, M.E.; Sajjadi, F. Competency-based medical education and meta-competencies in general physician. Educ. Strateg. Med. Sci. 2017, 9, 471-474.

49. Rao, S.K.; Kimball, A.B.; Lehrhoff, S.R.; Hidrue, M.K.; Colton, D.G.; Ferris, T.G.; Torchiana, D.F. The impact of administrative burden on academic physicians: Results of a hospital-wide physician survey. Acad. Med. 2017, 92, 237-243. [CrossRef] [PubMed]

50. Saberi Zafarghandi, M.B.; Dadfar, M.; Arezoomandan, R.; Veisy, F.; Behnood Rod, A. Evaluation and Comparison of Short Form Methadone Maintenance Treatment Training Courses Among Iranian General Physician and Psychologist Participants. Illn. Crisis Loss 2019. [CrossRef]

51. Khorram-Manesh, A. The Development of Swedish Military Healthcare System: Part II-Re-evaluating the Military and Civilian Healthcare Systems in Crises Through a Dialogue and Study Among Practitioners. Mil. Med. 2020, 186, e442-e450. [CrossRef]

52. Reas, D.L.; Rø, Ø. Time trends in healthcare-detected incidence of anorexia nervosa and Bulimia nervosa in the Norwegian national patient register (2010-2016). Int. J. Eat. Disord. 2018, 51, 1144-1152. [CrossRef]

53. The European Observatory on Health Systems and Policies. Poland Hit. 2019. Available online: https://www.euro.who.int/en/ about-us / partners / observatory / publications/health-system-reviews-hits/full-list-of-country-hits/poland-hit-2019 (accessed on 5 March 2021).

54. Golinowska, S.; Sowada, C. What's next for healthcare in Poland: Diagnosis and prognosis. In mBank-CASE Seminar Proceedings (No. 156); Casa: Warsaw, Poland, 29 November 2018; Available online: https:/ / papers.ssrn.com/sol3/papers.cfm?abstract_id=33 00784 (accessed on 5 March 2021).

55. Błażejczyk, A.; Błażejczyk, K.; Baranowski, J.; Kuchcik, M. Heat stress mortality and desired adaptation responses of healthcare system in Poland. Int. J. Biometeorol. 2018, 62, 307-318. [CrossRef]

56. Ahgren, B. The path to integrated healthcare: Various Scandinavian strategies. Int. J. Care Co-Ord. 2014, 17, 52-58. [CrossRef]

57. The European Observatory on Health Systems and Policies. Assessing Chronic Disease Management in European Health Systems: Concepts and Approaches. 2014. Available online: https://www.euro.who.int/en/about-us/partners/observatory/ publications / studies/assessing-chronic-disease-management-in-european-health-systems-concepts-and-approaches-20 14 (accessed on 5 March 2021). 
58. The European Observatory on Health Systems and Policies. Assessing Chronic Disease Management in European Health Systems: Country Reports. 2015. Available online: https:/ /www.euro.who.int/en/about-us/partners/observatory/publications/studies/ assessing-chronic-disease-management-in-european-health-systems-country-reports-2015 (accessed on 5 March 2021).

59. Chaix, B.; Merlo, J.; Chauvin, P. Comparison of a spatial approach with the multilevel approach for investigating place effects on health: The example of healthcare utilisation in France. J. Epidemiol. Community Health 2005, 59, 517-526. [CrossRef]

60. Evans, N.; Bausewein, C.; Menaca, A.; Andrew, E.V.; Higginson, I.J.; Harding, R.; Pool, R.; Gysels, M.A. A critical review of advance directives in Germany: Attitudes, use and healthcare professionals' compliance. Patient Educ. Couns. 2012, 87, 277-288. [CrossRef] [PubMed]

61. Prospero, E.; Galmozzi, S.; Paris, V.; Felici, G.; Barbadoro, P.; D’Alleva, A.; Zocco, G.; Ciavattini, A. Factors influencing refusing of flu vaccination among pregnant women in Italy: Healthcare workers' role. Influ. Other Respir. Viruses 2019, 13, $201-207$. [CrossRef] [PubMed]

62. Reckers-Droog, V.T.; Van Exel, N.J.A.; Brouwer, W.B.F. Looking back and moving forward: On the application of proportional shortfall in healthcare priority setting in the Netherlands. Health Policy 2018, 122, 621-629. [CrossRef]

63. Leichsenring, K. Developing integrated health and social care services for older persons in Europe. Int. J. Integr. Care 2004, 4, e10. [CrossRef]

64. Newhouse, N.; Lupiáñez-Villanueva, F.; Codagnone, C.; Atherton, H. Patient use of email for health care communication purposes across 14 European countries: An analysis of users according to demographic and health-related factors. J. Med. Internet Res. 2015, 17, e58. [CrossRef]

65. Nolte, E.; Knai, C. (Eds.) Assessing Chronic Disease Management in European Health Systems; Country Reports; WHO Regional Office for Europe on Behalf of the European Observatory on Health Systems and Policies: Copenhagen, Denmark, 2015.

66. Baxter, S.; Johnson, M.; Chambers, D.; Sutton, A.; Goyder, E.; Booth, A. The effects of integrated care: A systematic review of UK and international evidence. BMC Health Serv. Res. 2018, 18, 350. [CrossRef]

67. Pinter, K.A.; Zhang, H.; Liu, C.; Tran, B.; Chokshi, M.; Lucerno-Prisno, D.E.; Sharma, V.; Tang, S. Elements and Performance Indicators of Integrated Healthcare Programmes on Chronic Diseases in Six Countries in the Asia-Pacific Region: A Scoping Review. Int. J. Integr. Care 2021, 21. [CrossRef]

68. Ariani, A.; Koesoema, A.P.; Soegijoko, S. Innovative healthcare applications of ICT for developing countries. In Innovative Healthcare Systems for the 21st Century; Springer: Cham, Switzerland, 2017; pp. 15-70.

69. Papp, R.; Borbas, I.; Dobos, E.; Bredehorst, M.; Jaruseviciene, L.; Vehko, T.; Balogh, S. Perceptions of quality in primary health care: Perspectives of patients and professionals based on focus group discussions. BMC Fam. Pr. 2014, 15, 128. [CrossRef]

70. Merkin, R. Systems and Methods for Assessing and Optimizing Healthcare Administration. U.S. Patent Application No 12/834,767, 12 July 2010.

71. Flores, M.; Glusman, G.; Brogaard, K.; Price, N.D.; Hood, L. P4 medicine: How systems medicine will transform the healthcare sector and society. Pers. Med. 2013, 10, 565-576. [CrossRef] [PubMed]

72. Jones, R. Hospital beds per death how does the UK compare globally? Br. J. Health Manag. 2018, 24, 617-622. [CrossRef]

73. Jones, R.P. A pragmatic method to compare hospital bed provision between countries and regions: Beds in the States of Australia. Int. J. Health Plan. Manag. 2020, 35, 746-759. [CrossRef] [PubMed]

74. Jones, R.P. How many medical beds does a country need? An international perspective. Br. J. Health Manag. 2020, 26, 248-259. [CrossRef]

75. Committee on Bioethics. Palliative care for children. Pediatrics 2000, 106, 351-357. [CrossRef]

76. Greer, S.L. Devolution and health in the UK: Policy and its lessons since 1998. Br. Med Bull. 2016, 118, 16-24. [CrossRef]

77. Hopson, C. Can the NHS as we know it reach its 100th birthday or is it now in palliative care? Medico-Legal J. 2020, 88 (Suppl. 1), 5-14. [CrossRef]

78. Gramling, R.; Gajary-Coots, E.; Cimino, J.; Fiscella, K.; Epstein, R.; Ladwig, S.; Anderson, W.; Alexander, S.C.; Han, P.K.; Gramling, D.; et al. Palliative care clinician overestimation of survival in advanced cancer: Disparities and association with end-of-life care. J. Pain Symptom Manag. 2019, 57, 233-240. [CrossRef]

79. Beard, J.R.; Officer, A.M.; Cassels, A.K. The world report on ageing and health. Gerontologist 2016, 56, S163-S166. [CrossRef]

80. Skopec, M.; Issa, H.; Harris, M. Delivering cost effective healthcare through reverse innovation. BMJ 2019, 367, 16205. [CrossRef]

81. Moussa, L.; Garcia-Cardenas, V.; Benrimoj, S. Change Facilitation Strategies Used in the Implementation of Innovations in Healthcare Practice: A Systematic Review. J. Chang. Manag. 2019, 19, 283-301. [CrossRef]

82. Steenbergen, H.A.; de Jong, B.I.; Fleuren, M.A.; van der Schans, C.P.; Waninge, A. Examining determinants of lifestyle interventions targeting persons with intellectual disabilities supported by healthcare organizations: Usability of the Measurement Instrument for Determinants of Innovations. J. Appl. Res. Intellect. Disabil. 2019, 32, 913-931. [CrossRef]

83. Boyer, R. How scientific breakthroughs and social innovations shape the evolution of the healthcare sector. In Innovation Beyond Technology; Springer: Singapore, 2019; pp. 89-119.

84. Brogan, J. Expand your Pareto Principle: 80-20 metrics can evaluate viability of numerous endeavors. Ind. Eng. 2010, 42, 45-50.

85. Wright, A.; Bates, D.W. Distribution of problems, medications and lab results in electronic health records: The Pareto principle at work. Appl. Clin. Inform. 2010, 1, 32-37.

86. Sapci, A.H.; Sapci, H.A. Digital continuous healthcare and disruptive medical technologies: M-health and telemedicine skills training for data-driven healthcare. J. Telemed. Telecare 2018, 25, 623-635. [CrossRef] [PubMed] 
87. Le, L.B.; Rahal, H.K.; Viramontes, M.R.; Meneses, K.G.; Dong, T.S.; Saab, S. Patient satisfaction and healthcare utilization using telemedicine in liver transplant recipients. Dig. Dis. Sci. 2018, 64, 1150-1157. [CrossRef] [PubMed]

88. Goniewicz, K.; Khorram-Manesh, A.; Hertelendy, A.J.; Goniewicz, M.; Naylor, K.; Burkle, F.M. Current response and management decisions of the European Union to the COVID-19 outbreak: A review. Sustainability 2020, 12, 3838. [CrossRef]

89. Khorram-Manesh, A.; Carlström, E.; Hertelendy, A.J.; Goniewicz, K.; Casady, C.B.; Burkle, F.M. Does the prosperity of a country play a role in COVID-19 outcomes? Disaster Med. Public Health Prep. 2020, 1-20. [CrossRef]

90. Burkle, F.M.; Bradt, D.A.; Ryan, B.J. Global Public Health Database Support to Population-Based Management of Pandemics and Global Public Health Crises, Part I: The Concept. Prehospital Disaster Med. 2021, 36, 95-104. [CrossRef]

91. Burkle, F.M.; Bradt, D.; Green, J.; Ryan, B. Global Public Health Database Support to Population-Based Management of Pandemics and Global Public Health Crises, Part II: The Database. Prehospital Disaster Med. 2020, 1-6. [CrossRef]

92. Parnell, A.; Goniewicz, K.; Khorram-Manesh, A.; Burkle, F.M.; Al-Wathinani, A.; Hertelendy, A.J. COVID-19 a health reform catalyst?-Analyzing single-payer options in the US: Considering economic values recent proposals and existing models from abroad. J. Hosp. Admin. 2020, 9, 10-19. [CrossRef]

93. Kobelt, G.; Thompson, A.; Berg, J.; Gannedahl, M.; Eriksson, J. MSCOI Study Group, European Multiple Sclerosis Platform. New insights into the burden and costs of multiple sclerosis in Europe. Mult. Scler. J. 2017, 23, 1123-1136. [CrossRef]

94. Bauer, J.; Brüggmann, D.; Klingelhöfer, D.; Maier, W.; Schwettmann, L.; Weiss, D.J.; Groneberg, D.A. Access to intensive care in 14 European countries: A spatial analysis of intensive care need and capacity in the light of COVID-19. Intensiv. Care Med. 2020, 46, 2026-2034. [CrossRef]

95. Dahl-Popolizio, S.; Doyle, S.; Wade, S. The role of primary health care in achieving global healthcare goals: Highlighting the potential contribution of occupational therapy. World Fed. Occup. Ther. Bull. 2018, 74, 8-16. [CrossRef]

96. Wang, H.; Li, T.; Gauthier, S.; Yu, E.; Tang, Y.; Barbarino, P.; Yu, X. Coronavirus epidemic and geriatric mental healthcare in China: How a coordinated response by professional organizations helped older adults during an unprecedented crisis. Int. Psychogeriatr. 2020, 32, 1117-1120. [CrossRef] [PubMed]

97. Wernhart, A.; Gahbauer, S.; Haluza, D. eHealth and telemedicine: Practices and beliefs among healthcare professionals and medical students at a medical university. PLOS ONE 2019, 14, e0213067. [CrossRef]

98. Sturmberg, J.P.; O'halloran, D.M.; Martin, C.M. Understanding health system reform-a complex adaptive systems perspective. J. Eval. Clin. Pract. 2012, 18, 202-208. [CrossRef]

99. Goniewicz, K.; Goniewicz, M.; Burkle, F.M.; Khorram-Manesh, A. Cohort research analysis of disaster experience, preparedness, and competency-based training among nurses. PLoS ONE 2021, 16, e0244488. [CrossRef]

100. Goniewicz, K.; Goniewicz, M.; Włoszczak-Szubzda, A.; Burkle, F.M.; Hertelendy, A.J.; Al-Wathinani, A.; Molloy, M.S.; KhorramManesh, A. The importance of pre-training gap analyses and the identification of competencies and skill requirements of medical personnel for mass casualty incidents and disaster training. BMC Public Health 2021, 21, 1-11. [CrossRef]

101. Ahmed, Z.; Mohamed, K.; Zeeshan, S.; Dong, X. Artificial intelligence with multi-functional machine learning platform development for better healthcare and precision medicine. Database 2020, 2020. [CrossRef]

102. Khorram-Manesh, A.; Phattharapornjaroen, P.; Mortelmans, L.J.; Goniewicz, K.; Verheul, M.; Sörensen, J.L.; Pereira, I.; Ricklin, M.E.; Faccincani, R.; Dark, P.M.; et al. Current perspectives and concerns facing hospital evacuation: The results of a pilot study and literature review. Disaster Med. Public Health Prep. 2021, 1-9. [CrossRef] [PubMed] 